\title{
PLAY, WORK AND EDUCATION: SITUATING A FROEBELIAI DEBATE
} Juego, trabajo y educación: situando un debate froebeliano

\author{
KEVIN J. BREHONY \\ University of Roehampton
}

Currently, the place of play in schooling and education is controversial. Even in pre-school, where play is most likely to be found, its status is often precarious. This article notes that in many ancient religious traditions, play is sometimes viewed as sinful, whereas work, its antithesis, is seen as virtuous. The German educationist, Friedrich Froebel, departed radically from these evaluations and devised a system of educative play based on toys and games to be used in his institution for the education of young children, the kindergarten. Nevertheless, while at the same time as being a prominent advocate of the notion that play was a worthwhile and necessary part of an early childhood curriculum, Froebel thought it subordinate in value to what it was intended to lead to, work of a manual nature.

The reading of Froebel and the Froebel Movement presented here situates his conceptions of play and work within the intellectual context of German Romanticism and Idealist philosophy. The main contours of thought on play and work are traced in the writings of Kant, Schiller, Hegel and Marx, through a consideration of work as both emancipatory and alienating. This theme is pursued in the thought of leading English Romantics and various figures within the Marxist tradition, including some attached to Soviet ideology.

It is argued that the Froebel revisionists, like Schrader Breymann and many Froebelians inspired by G. Stanley Hall and John Dewey, tended to abandon the view of work embraced by Froebel and focused more on play, aided by the interests and findings of the developing field of psychology and the lengthening of compulsory schooling.

Key words: Play, work, Froebel, kindergarten, Romanticism, Idealism.

This article presents a reading of the work of the German educationist, Friedrich Froebel (1782-1852) and his immediate successors as leaders of the kindergarten movement. In particular, it focuses on Froebel's conception of play and its role in early childhood education. It is contended that although Froebel was a strenuous advocate of play he always regarded it as subordinate, and a preliminary, to work. Education through and for work was Froebel's principal aim. In order to understand more fully how play could turn into its apparent antithesis, Froebel's thought is located within its intellectual context that was comprised, in the main, of German Romanticism and Idealist philosophy. Within that context, play and 
work possessed different meanings than they do today. To argue this case need not, and neither is it intended to, detract from the legitimation Froebel gave to play in the education of children in their earliest years. Instead, it aims to present a more complex account of Froebel's thinking on play than is currently provided and one that seeks to relate Froebel to intellectual movements outside the fields of early childhood education and education in general.

As is well known, Froebel was an advocate of young children learning through play and to that end he devised a system of toys and other educative materials known as the Gifts and Occupations. These, he believed, were logically related to each other and their sequence was related to the stages in a child's development. Moreover, each Gift and Occupation, Froebel thought, contained symbolic meanings, which the child had access to. Furthermore, in his book, Mother's Songs (Froebel, 2001d), he devised a set of games, finger plays, songs and illustrations that were designed to be used by a mother to educate her young child. While regarded widely as appropriate for young children in their early years, the use of educative play in schools has been widely resisted and criticized. Typically the argument is made that in school children should work not play as they do in the nursery school or kindergarten, and it is hoped that this article makes a contribution to why this should be (Brown and Freeman, 2001).

A central assumption informing this article is that debates about play in education and schooling are always framed by adult conceptions of work. An important exception is the discussions of play made by psychologists such as Piaget (1962), Vygotsky (1978) and Isaacs (Isaacs and Isaacs, 1930). They tended to focus on the part played by play in child development but, as is common with much psychology, they ignored the wider context, which was largely deaf to their accounts of the significance of play in early childhood. As a general rule, play's «other» in the form of work has nearly always accompanied discussions of play in relation to schooling.

Without going far beyond the first moves in a Derridean deconstruction of the play/work binary opposition it is evident that, as he claims, «One of the two terms governs the other» (Derrida, Bass et al., 1981: 41). In this instance, the governing term is «work». This may be demonstrated by looking at the history of the binary in religious discourse in which work was associated with the Biblical version of the fall. Among many later illustrations is the rule of Saint Benedict in which work had a central place. Saint Benedict wrote that, «Idleness is the enemy of the soul» (Benedict and Blair, 1886) and some of the English Protestant reformers, known as Puritans, dismissed children's play as sinful (Hughes, 2009); but there is another discourse, which has religious roots but tends to regard work and play not as opposed to each other but as connected. This view is present in Froebel's work, among others, and in it, play in early childhood, although valued, is nonetheless subordinated to work.

The dominance of work over play is related to another opposition, that between childhood and adulthood in which it is adulthood that is the most positively evaluated. Play is interleaved with childhood and for centuries as in the Biblical quotation, "When I was a child, I spoke as a child, I understood as a child, I thought as a child: but when I became a man, I put away childish things» (1 Corinthians, 13: 11). It was something to be left behind in the transition to adulthood in favour of work. The Protestant reformer, John Wesley who founded the Methodist Church in England did not approve of play even in childhood. Writing of Kingswood School which he founded in 1748, he explained how no time was allocated for play and he quoted approvingly a German proverb, «he that plays when 
he is a boy, will play when he is a man» (Wesley, 1841: 279).

Resonances of the child to adult diachrony occur also in Freud's notion of the pleasure principle (Freud and Hubback, 1922) and its supersession by the reality principle.

With the rise of compulsory mass schooling in the advanced capitalist countries during the nineteenth century another associated binary was introduced. This was that between the school and the family from which the former captured educational functions previously performed by the latter. During this transition as Wallerstein suggests, productive work that children previously did mainly, but not exclusively, in the household was now devalued. Rather incredulously he asserts that children's training activities in school were labeled as «fun» (Wallerstein, 2011: 26). The extent to which schoolwork was experienced as fun or intended to be so is a matter for some dispute but due to the introduction of compulsory attendance, schoolwork for the children of the masses certainly replaced productive work. This, created a specific kind of work divorced from immediate, productive work for children and youth in school time which in popular songs was contrasted with after school time or leisure (Brehony, 1998).

\section{Froebel's Kindergarten}

Not wanting to provide another type of school for children under the age of six, Froebel developed his kindergarten concept to occupy a position between the family and the school. It was intended to assist the family in the education of young children and at the same time provide educational experiences that would enable the child to learn once at school. It occupies, therefore an ambiguous, if not contradictory position, due to the kindergarten being conceived of as a place where children learn to play (Froebel, 1875: 3). Explaining Froebel's choice of the name kindergarten for his institution his nephew, Karl Froebel, pointed out that «play-school», a possible alternative name, would be a contradiction in terms, (Froebel, 1875: 180). The implication was that education through play could only take place in a kindergarten and not in school.

Friedrich Froebel, wrote poetically about the plays of childhood calling them, «the germinal leaves of all later life» (Froebel, 2001c: 55) and like the German Romantic writer, Jean Paul Richter (1763-1825) (Richter, 1891) many of whose ideas on education he shared, Froebel contested the view that play was trivial and lacked seriousness. Given how much he thought, observed and wrote about children's play, it is curious that Froebel rarely moved beyond its description to provide a definition. Instead he provided a sketch of how play was transformed into work as the child developed. In early childhood, he thought that play; consisted solely of activity but in «boyhood», it had a «definite conscious purpose» and in this stage, it «sought representation» (Froebel, 2001a: 112-113). Whereas in childhood, activity brought joy, in boyhood it was work that gave delight. The examples of work he gave tended to be domestic or rural tasks that grew out of the mimesis of adult occupations. Play, now the child had reached boyhood and school, did not disappear, however, but was no longer dependent on the Gifts and Occupations and the other activities of the kindergarten. Now, it consisted mainly of games, trials and display of strength. All of which were subordinate in school to the «subjects of knowledge».

\section{Schiller's theory of play}

Unlike the poet and dramatist, Friedrich von Schiller (1759-1805), Froebel did not have a fully developed theory of play even though he 
made several references in his letters to Schiller's work, On the aesthetic education of Man in which Schiller's own theory appears (Schiller, 1994). Schiller, following a discussion by Kant in his Critique of Judgement, linked art to play and beauty and thus began a key theme in the subsequent debates around play and aesthetics (Sutton-Smith, 2001). Kant had argued that art was like play, «an occupation that is pleasant in itself» and not, like work, «compulsorily imposed» (Kant and Bernard, 1914: 184).

Froebel did not make explicit reference to Schiller's, surplus energy theory of play nor to his notion of a play instinct. His most overt reference to Schiller's thought on play appeared in a letter written in 1847 in which he said that, "any educational work [...] founded upon play as a means of developing childhood, is work in the spirit of Schiller». Froebel did however, refer frequently to a child's «impulse to activity», and also to an impulse «to employment, and to representation» (Froebel, 2001c: 60). In addition, Froebel made a link between play and art similar to the one made by Schiller.

\section{Bildung and activity}

Froebel was immersed in the thought of the Frühromantik, or early Romantic Movement, that emanated from Jena in one of the German states in the early years of the nineteenth century. He shared with it an interest in the work of the Christian theosophist, Jakob Boehme (1575-1624) and with esotericism, Neoplatonism, Pythagorean numerology, panentheism and Naturphilosophie (Brehony, 2010). Beiser argues that in spite of this apparent celebration of irrationality and hostility to the Aufklärung or enlightenment and its valorization of reason, early romanticism shared with the Aufklärer a commitment to Bildung (Beiser, 2003). This complex term may be translated in a general sense as education, but self-realization captures it better. Significantly for this discussion, in Alexandre Kojève's reading of the great idealist philosopher, Georg Wilhelm Friedrich Hegel (1770-1831), who held that, «an individual cannot know what he is until he has made himself a reality through action», work is Bildung. This is warranted by Hegel's famous master-servant dialectic in Phenomenology of Spirit (Hegel and Findlay, 1979) and in his lectures on fine art when he says that, «man brings himself before himself by practical activity» (Hegel, 1998: 31). Nevertheless, whatever constituted action and activity for Hegel, it certainly did not encompass education through play, as he specifically criticised pedagogy intended for «boyhood» that was based on play (Hegel, Boumann et al., 1971: 60). As has been seen, this position is not as far away from Froebel's as may at first be assumed. Neither was Hegel's notion of children possessing an impulse to the «practical alteration of external things' in order to «produce himself» (Hegel, 1998: 31). The example he gives of a boy throwing stones in a river and creating circles on the water is one that many would have no difficulty in defining as play.

\section{Work, expressivism and mystical humanism}

For the philosopher, Charles Taylor, Romanticism was accompanied by a turn to nature for sources of identity. In turn, this necessitated articulating or expressing the impulses of nature within. Thus, he labels this new insight «expressivism» (Taylor, 1989: 374). The term Froebel frequently used for a similar process was «unfolding». For him, relative to work, play occupied a minor role in the «self-active representation of the inner», this was his description of play in The Education of Man. Play's main significance is indicated by Froebel in his statement that it was preparation for «future industry, diligence and productive industry» (Froebel, 2001a). 
Two assumptions led Froebel to this conclusion. The first was his panentheist notion shared with the one-time Masonic philosopher, Karl Christian Krause (1781-1832) that God was immanent and active in the universe rather like the demiurge in the Platonic traditions. In a trope common to Romanticism, Froebel personifies God as an artist. Each thought of God, he wrote, «continues to work with creative power in endless productive activity». As God created man in his own image, he asserted, «man should create and bring forth like God» (Froebel, 2001a: 30-31).

Froebel's second assumption, which was related to the first, concerned the nature of work. He criticized «the popular notions of work» by declaring them to be, «wholly false, superficial, untenable, oppressive, debasing, devoid of all elements of life» (Froebel, 2001a: 30). In addition, he criticised as debasing the «illusion that man works, produces, creates only in order to preserve his body, in order to secure food, clothing, and shelter...» and countered this by affirming that the great purpose of, «work, industry and of productive, creative activity was to become godlike» and thereby rise to true knowledge of God.

This example of «mystical humanism», as Gibbons labels it (Gibbons, 2001), lay at the centre of Froebel's educational thought which also resonated with Neo-Platonism (Cleary, 1997; Lloyd, 1998), as when he declared that the end of education was «unity with God» (Froebel, 2001a: 5). What this required in terms of educational practice, Froebel concluded, was that young children should be «trained early for outer work, for creative and productive activity» (Froebel, 2001a: 34).

Later, in the Education of Man, when discussing the nature of the education to be provided by the family and the school in the phase of boyhood, Froebel returned to his theme of the desirability of the inclusion of «some external pursuit, some externally productive work». He suggested that this might take the form of domestic duties such as errands. An education like this that was based on activity was explicitly defined against that provided in the Latin and high schools, in which Froebel claimed, «the pupils are wholly debarred from outwardly productive work» and argued, in what for him was a rare appeal to experience, that it showed that, «external, physical, productive activity interspersed in intellectual work strengthens not only the body but in a very marked degree the mind in its various phases of development, so that the mind, after such a refreshing work-bath (I can find no better name), enters upon its intellectual pursuits with new vigor and life» (Froebel, 2001a: 236-237).

\section{Froebel's inclusion of work in education}

At the school at Keilhau he founded and ran before he turned his attention to the education of young children, Froebel introduced manual work. Recollecting his days there as a pupil, the Egyptologist and novelist, Hans Georg Ebers (1837-1898) wrote of the tools he learned to use as well as the Latin classes and games played in the forest. In 1829 Froebel also prepared a scheme for a People's Educational Institute to be founded at Helba, on the estate of the Duke of Meiningen, (Froebel, Moore et al., 1915: 129-130), that would combine subject knowledge with manual labour or «creative activity» and play (White, 1905: 29-36). Nothing was to come of this scheme, due to political opposition from within the Duke's court but Froebel's advocacy of manual work at Keilhau also provoked opposition from the school's middle and upper class parents who, «were unwilling to have... customary school learning shortened and supplanted in any way by practical work whose importance for the purely educational side of culture was incomprehensible to them» (Marenholtz-Bülow, Mann et al., 1877: 324). This may indicate that for such parents, subject knowledge possessed a high 
status; something that play and manual work did not and they were not prepared to forgo that status for Froebel's innovations.

In summary, Froebel's is a theory of self-realization, of unfolding through activity, of play followed by work but if the Education of Man was the only text of Froebel's that we had, it is conceivable that he would have been regarded not as an advocate of play in education but, like many contemporary educationists like Robert Owen, von Fellenberg and Pestalozzi, as a proponent of work. Like them he thought that one form that children's work took was the imitation of adults. Hence the examples he gave of domestic work. He also thought of it as involving manual dexterity that would be useful for «the training of poorer children» (Froebel, 2001b: 337-340). Significantly, there is little room in his view of work for what we conventionally call learning or formal instruction. When he opposed play to work, he followed Rousseau's rejection of passive learning and learning from books.

\section{Baroness Bertha von Marenhotz-Bülow's reading of Froebel on play and work}

After his death, Froebel's acknowledged successor of the kindergarten movement in Europe, the Baroness Bertha von Marenhotz-Bülow (18101893) gave his work on play a distinct inflection which made it quite explicitly subordinate to work. Writing at the moment that the German states began to industrialise, she adopted the vocational justification that the kindergarten paved the way, «for a training for labour, such as the pressing wants of the age demand, and to fit the labouring classes for earning their bread...» (Marenholtz-Bülow, 1854: 4). Markedly, this emphasis on the inculcation of skills and habits of work for vocational reasons is almost entirely absent from Froebel's work.

It was von Marenhotz-Bülow who produced the Orwellian aphorism, «play is the work of the child» (Marenholtz-Bülow, 2001: 55), which is widely misattributed to Froebel, and her writing left her readers in no doubt of the desirability of inculcating work habits into the «masses» whose coarse and rough behaviour had caused her both consternation and anxiety during the revolutions of 1848 (MarenholtzBülow, 1887: 204). Von Marenholtz-Bülow thought Froebel's view that the social classes should be mixed in the kindergarten was utopian (Marenholtz-Bülow, Mann et al., 1876: 31). Unlike Froebel who held a view of the kindergarten as inclusive of all religions and social classes, fixed her gaze firmly on the Bewahranstalt or day care centres, pauper schools and orphanages, institutions formed specifically for poor children of the working class, which she hoped, could be transformed into kindergartens.

\section{Specifics-playground and free play}

The Scottish educationalist, David Stow (17931864) referred to the play-ground as an «uncovered school-room» (Stow, 1847: 9). Stressing its role in moral development, he was expressing a view similar to that of the British infant school pioneers, Robert Owen (17711858) (Owen, 1813) and Samuel Wilderspin (1791-1866). For the latter, supervised playgrounds were places where moral training could occur (Wilderspin, 1834). For Froebel too, they were places for the cultivation of «civic and moral virtues' (Froebel, 2001a: 114). The Baroness Von Marenholtz-Bülow, thought similarly, arguing that left to themselves, «in the streets and public play-grounds without guidance or elevating occupations» children develop bad habits but, she wrote, «it is a mistake to suppose that children prefer the wild lawless pastimes that are carried on in the streets to well-regulated play» (MarenholtzBülow, 1883: 106). Following Froebel's practice, she suggested that children's games, street games included, should be incorporated into regulated play spaces once the, "coarse and unseemly» elements were eliminated. 
This emphasis on regulated freedom for the working class child was typical of German liberals who were caught between the repression of the Junkers or the landed aristocracy and the emergent working class (Allen, 1982). Marenholtz-Bülow was concerned to find ways to restrain the «rough masses» whose children out of school, she observed, relapsed «into the condition of savages» (Marenholtz-Bülow, 1883: 131) and this coloured her views on free play. To those, like Eugenio Bartolomé y Mingo (1839-1920) in Madrid, who argued that the over-regulation of children's play destroyed their freedom, she responded that in the kindergarten when children played supervised by the teacher without the teacher interfering with their play, they invariably asked the teacher to lead their games (Marenholtz-Bülow, 1883).

\section{Work as play and creativity}

Marenholtz-Bülow enunciated a theme that was to resonate among many subsequent educationalists when she asserted that if strength, skill and pleasure had been attained through activity, later on actual work, «will then be loved for its own sake, will produce enjoyment, and will, in many cases, be as good as play» (Marenholtz-Bülow, 1883: p. 91). Elsewhere, she wrote, «children, unconsciously and even while at play are fashioned into work-men». Nevertheless, this transformation was predicated on the «curse of labour' perspective on work (Marenholtz-Bülow, 1883: 25). As the Baroness was determined that work be «spiritualised», she had little to say about the negative side of work. Occasionally, as when she wrote that «the great bulk of the working-classes consists of daylabourers who are little better than beasts of burden, or machines, without human dignity or self-respect», this uncongenial aspect of the work performed by the working-class was illuminated (Marenholtz-Bülow, 1883: 4).

In praising work and generally ignoring drudgery (Spencer, 2009), work's negative side,
Marenholtz-Bülow was at one with Froebel who only rarely admitted that work might have one, as when he wrote of the kindergarten occupations that, "proper education develops man even at an early age for a future securing of his subsistence, without early deadening him to a machine among machines» and such an education would lessen «proletarianism» and restore to work its «high significance» (Froebel, 2001c: 40). It is tempting here to read this as a reference to the transformation of work due to industrialization and machinofacture but his letters and other writing provide little warrant for this. All that may be said with confidence, is that his references to machines tend always to be pejorative.

However, that work was unfree was also recognized by Froebel who thought his «occupationmaterial» could transform work into «free activity», while, he declared, in a way anticipating the Frankfurt School, that, «at the present time art alone can truly be called free activity» (Marenholtz-Bülow, Mann et al., 1877: 238). In this, the artist is once more invoked as the paradigmatic of the creative worker. All work should be transformed into creative work, maintained Marenholtz-Bülow because the artists are able to express themselves and represent their inner being.

\section{Play and work in the Froebel Movement}

After Froebel's death, the Baroness von Marenholtz-Bülow led the Froebel movement and travelled around Europe tirelessly promoting her work (Bülow-Wendhausen, 1901). After the failed revolutions of 1848 in the German States, the kindergarten idea spread and was adopted in several European states, including Spain (Orzaes, 1991; Blanco and Berrio, 2010; Orzaes, 2010). There, one of the most prominent promoters and popularisers of Froebel's kindergarten, Pedro de Alcántara García (18421906) (Rodríguez Pérez, 2007), followed 
Froebel by arguing for play as a prelude to work (Payá Rico, 2006). This was in opposition to the view that play and work were separate, as endorsed by Froebel's grand niece, Henriette Schrader Breymann (1827-1899), who was challenging von Marenholtz-Bülow as leader of the kindergarten movement. As the kindergarten spread following the lifting of the Prussian ban, imposed on the grounds that the kindergartens taught atheism, it was constantly under pressure, as Schrader Breymann, complained, to become more like school (Breymann, Schrader et al., 1872). Her reading of Froebel led her to return to Pestalozzi and emphasise not play but education based on domestic occupations. Even when young at Keilhau she found it difficult to understand the reasoning behind the Gifts and Occupations. Later, in a letter written in 1882 referring to the Gifts, she wrote of the «angularity of the mathematical forms' that Froebel had provided. She also described them as, «cold, rigid conceptions of mathematical formulae». At the Pestalozzi Froebel House in Berlin which began as a kindergarten in 1873 , she wrote that there they did «not limit our work to the systematic developing of the Frobel occupations, but that we use the activities of daily life as the means of development to their full extent» (Lyschinska, 1922). Aimed at the children of the poorer classes, a description of their kindergarten curriculum indicates the extent of Schrader-Breymann's revision of Froebel's ideas. In the Pestalozzi Froebel House kindergarten provided:

«... free play of a child by itself; free play of several children by themselves; associated play under the guidance of a teacher (Froebel's Games); gymnastic exercises; several sorts of handiwork suited to little children; going for walks; learning music, both instrumental (on the method of Madame Wiseneder) and vocal learning and repetition of poetry; story-telling; looking at really good pictures; aiding in domestic occupations; gardening; and the usual systematic ordered occupations of Froebel».
The author added that, «Madame Schrader is steadfastly opposed to that conception of the Kindergarten which insists upon mathematically shaped materials» (Froebel, 2001b: 37).

The practices of the Pestalozzi Froebel House were emulated in Chicago and London but their impact was initially limited. In England during the 1880 s, a substantial section of the Froebel Movement turned to wood Sloyd and other forms of manual training and aligned themselves with the organic intellectuals of the industrial bourgeoisie who were promoting science education and manual training as a means to fend off international industrial competition (Brehony, 1998). In 1884, at the International Health Exhibition held in London, Eleonore Heerwart, formerly head of the British and Foreign School Society's Stockwell College Kindergarten department, read a paper entitled, «The Kindergarten in Relation to the Various Industrial Products of a Country». Between the Kindergarten occupations and the «nation's industries she argued, lay the training of hand and eye which accompanied the use of the Kindergarten apparatus...». She concluded that «the Kindergarten, viewed in this light, commends itself to the notice of employers in every country» (Heerwart, 1884: 104). In an article in the English Froebelian journal Child Life, Heerwart opined, providing further evidence of the conception of the kindergarten as a site for the production of labour, that, "If Pestalozzi succeeded in discovering the alphabet of knowledge, Froebel found the alphabet of work» (Heerwart, 1891: 23; original emphasis).

\section{Marx on Work and Labour}

Of wider significance than Froebel's views on work and play were those of Karl Marx. In a number of publications Löwy, together with Sayre (Sayre and Löwy, 1984; Löwy, 1987; Löwy and Sayre, 2001), has traced the connections between Marx's thought and anti-Capitalist Romanticism and from this perspective the 
similarities between Marx's view of the role of work or labour in self-creation and that of Froebel is unsurprising. Needless to add, that Marx's thinking on this matter was inflected by his engagement with Hegel's thought. Froebel, it should be noted, reportedly replied to the charge that his ideas bore similarities to Hegel's by saying he had not had the time to read Hegel (Marenholtz-Bülow, Mann et al., 1877: 225).

In the Economic and Philosophical Manuscripts of 1844, Marx wrote, «for the socialist man the entire so-called history of the world is nothing but the creation of man through human labour». "Free conscious activity» he declared, is the, «species-character of human beings». Unlike Froebel, however, Marx held that labour, when carried out under conditions of private property, was estranged or alienated. The consequence was that, «in his work... he does not affirm himself but denies himself, does not feel content but unhappy, does not develop freely his physical and mental energy» and labour in these conditions, is, «not voluntary, but coerced; it is forced labor. It is therefore not the satisfaction of a need; it is merely a means to satisfy needs external to it» (Marx, 1964). Moreover, a key effect of estranged labour was for, «man, just because he is a conscious being» to make, his «life activity, his being, a mere means for his existence». Engels, in his The Condition of the Working Class in England in 1844, put it similarly:

«As voluntary, productive activity is the highest enjoyment known to us, so is compulsory toil the most cruel, degrading punishment. Nothing is more terrible than being constrained to do some one thing every day from morning until night against one's will. And the more a man the worker feels himself, the more hateful must his work be to him, because he feels the constraint, the aimlessness of it for himself» (Engels and McLellan, 2009: 129).
The affinities between the views of Marx and Engels on work and Froebel's criticism of the popular view of work may easily be seen.

\section{Marx and Hegel on Work, Play and Education}

In Capital vol 1, Marx outlined a sketch of the education of the future. Citing Robert Owen's belief in combining education with labour, Marx wrote that it would, «in the case of every child over a given age, combine productive labour with instruction and gymnastics, not only as one of the methods of adding to the efficiency of production, but as the only method of producing fully developed human beings» (Marx, 1977: 614).

Like Hegel, Marx can be read as opposing education through play (Small, 2005). Moreover, he did not think, as did many Froebelians, that work should be made like play. Criticising the French, utopian socialist Charles Fourier (1772-1837), who held this view (Zeldin, 1969; Pearson, 2002), Marx argued that really free working is «the most damned seriousness, the most intense exertion» (Marx, 1973: 611). Later, he declared, «Labour cannot become play as Fourier thought» (Marx, 1973: 712).

A question left, at best, unresolved by Marx is whether non-alienated labour is possible under capitalism or in some future post-Capitalist society (Sayers, 2011). However, he did imply that art was the highest form of free creative activity and here again there are parallels with Froebel's thought.

\section{Marcuse revives play}

This debate on alienation, work, art and play within the broad Marxist tradition fell dormant for several decades until Herbert Marcuse (1898-1979) of the Frankfurt School revived it following the publication of his book Eros and 
Civilization in 1955. (Marcuse, 1969). Combining Hegelian Marxism with an appropriation of Freud, Marcuse argued that due to technological advances, the conditions that sustained alienated labour and repressive civilization could be abolished and, drawing on Schiller and Fourier, he wrote, «In a genuinely humane civilization, the human existence will be play rather than toil, and man will live in display rather than need» (Marcuse, 1969, p. 188). Marcuse's theoretical edifice, containing as it did, selective readings of Marx and Freud was not without its critics (Kellner, 1984). Among them was his Frankfurt School colleague, Theodor W. Adorno (1903-1969), who arguing, against the play theorist, Huizinga (Huizinga, 1998), claimed that play was repetitive and an after-image of repressive labour and thus, routinized, not emancipator (Adorno et al., 1997).

\section{Work and the English Romantic tradition}

Moreover, while Marcuse's notion of transforming work into play resonated with the ideas of Fourier and Froebel, a good deal of the Romantic tradition in England, at least, was concerned with the gospel of work. Thomas Carlyle (1795-1881) wrote that idleness leads to «perpetual despair» whereas «Labour is Life: from the inmost heart of the Worker rises his god-given Force, the sacred celestial Lifeessence breathed into him by Almighty God» (Carlyle, 1870: 246). The art-historian and critic, John Ruskin (1819-1900), followed Carlyle in ascribing ultimate value to work but he thought that the connection he saw between work, art and beauty in the Middle Ages, had been destroyed by capitalism. Work under capitalism turned «operatives» into machines and was, he considered, degrading and alienating (Ruskin, 2007: 163).

This was a diagnosis that the writer, artist and revolutionary socialist, William Morris (1834-1896) concurred with. In his utopian novel, News from Nowhere first published in 1890, describing work after the revolution he wrote, «it is each man's business to make his own work pleasanter and pleasanter» (Morris and Wilmer, 2004: 128). Freed from over-work, he declared in a manner resonant of Fourier, «art or work-pleasure, as one ought to call it... sprung up almost spontaneously» motivated by, «a kind of instinct amongst people..., to do the best they could with the work in hand» and then, «by a craving for beauty» (Morris and Wilmer, 2004: 160). All this should now be familiar but where Morris differed from the Froebelians and the Romantics was that for work to become more like play and art, a revolution was first necessary. Morris also contemplated the kind of education that might be offered in a post revolutionary society. He has a character in his novel explain that, «We don't encourage early bookishness... you see, children are mostly given to imitating their elders, and when they see most people about them engaged in genuinely amusing work, like house-building and street-paving, and gardening and the like, that is what they want to be doing» (Morris and Wilmer, 2004: 68). This passage contains echoes of Froebel and before him, Rousseau and Pestalozzi.

\section{Vocational Schooling: Kerchensteiner and Dewey}

In English state-provided schooling for the working class, little attention was paid to these Romantic conceptions of work, although legitimations for the introduction of manual work into the school curriculum tended to be cast in terms of its educative rather than its vocational benefits (Ricks, 1889; Goetze, 1894; Holman, 1921). Toward the end of the nineteenth century, the elementary school curriculum for older pupils, in common with international developments (Oelkers, 2006), began to include vocational subjects such as Laundry, Dairy Work and Housewifery for girls and Gardening 
for boys. Rather disingenuously, the Board of Education in Britain rejected the claim that these subjects had a vocational aim. The purpose of Gardening was not that of «putting boys as apprentices to the gardeners craft» and Housewifery was not «for training children for domestic service» (Great Britain. Board of Education, 1912, p. 19). In other parts of Europe and in the United States, vocational schooling, which contrasted sharply with the Romantic view of the place of work in education, began to gain ground. In Germany, Georg Michael Kerschensteiner (1854-1932) was prominent in this development (Röhrs, 1993). The ideas of the American, pragmatist philosopher and educationalist, John Dewey (1859-1952) bore several resemblances to those of Kerschensteiner but also had a number of important differences. As part of the discussion of vocational schooling, Dewey referred on a number of occasions to definitions of play and work and to their relation. In Democracy and Education, first published in 1916, he wrote:

«It is important not to confuse the psychological distinction between play and work with the economic distinction. Psychologically, the defining characteristic of play is not amusement nor aimlessness. It is the fact that the aim is thought of as more activity in the same line, without defining continuity of action in reference to results produced. Activities as they grow more complicated gain added meaning by greater attention to specific results achieved. Thus they pass gradually into work. Both are equally free and intrinsically motivated, apart from false economic conditions which tend to make play into idle excitement for the well to do, and work into uncongenial labor for the poor. Work is psychologically simply an activity which consciously includes regard for consequences as a part of itself; it becomes constrained labor when the consequences are outside of the activity as an end to which activity is merely a means. Work which remains permeated with the play attitude is art - in quality if not in conventional designation» (Dewey, 1921: 241-241).

Echoing Marx, he wrote that work performed under «unfree economic conditions» in which there was «external pressure or coercion» was actually drudgery.

By the time Dewey produced this definition, its' broad outline was generally accepted. Karl Froebel, for example, wrote something similar in 1875, «Play is mental life without an external object; work is the same but for the sake of an external object. Play has no purpose but its self» (Froebel, 1875: 74).

\section{The Soviet 'unified labour school'}

In many respects, the «unified labour school» (Pinkevitch and Counts, 1929; Hans and Hessen, 1930) conceived in the early years of the Soviet Union, in theory at least, was very close to Froebel's unsuccessful plan for a People's Educational Institute to be founded at Helba. Schooling that combined intellectual and manual labour, referred to as "polytechnic» education, was provided for pupils aged eight and over. This notion had roots in the fragmentary remarks on education and schooling made by Marx but, as has been seen, it had a much broader provenance.

Prior to the age of eight, Soviet children were to attend kindergartens and children's homes. Conditions of war and famine restricted their number but in their popularization of the Bolshevik programme, The ABC of Communism, first published in 1920, Nikolai Bukharin and Evgenii Preobrazhensky declared in a manner not inconsistent with Froebel, that, «A child's first activities take the form of play; play should gradually pass into work by an imperceptible transition, so that the child learns from the very outset to look upon labour, not as a disagreeable necessity or as a punishment, but as a natural 
and spontaneous expression of faculty» (Bukharin and Preobrazhensky, 2001). The labour school notion was applied in the kindergartens also (Kirschenbaum, 2001; Valkanova, 2009).

Even under Stalinism, Soviet ideology promoted the notion of the labour school, though by now, it was thoroughly vocational. Under Khrushchev it underwent something of a revival (Hans, 2011) and the idea of combining labour with school work persisted within the Marxist tradition.

\section{Célestin Freinet}

A prominent example is that of the French Marxist pedagogue, Célestin Freinet (18961966) and the movement that he created (Beattie, 2002). Freinet drew a distinction between play-work and work-play. Jeu-travail or play-work was free play, including imitative play, which could cross the line and become a dark, addictive, threatening, kind of play. Travail-jeu, or work-play on the other hand, was real work done by children (Freinet and Sivell, 1993). Play as work remained an attraction for other Marxists too, including C L R James, an independent revolutionary Marxist and former Trotskyist theoretician, who wrote in 1951 that, "Children's play is work - work which constantly challenges the child as an individual and as a social being. It is the new mode of labor - cooperative, creative, planned by the children themselves, developing a natural and spontaneous leadership, and obliterating all division between manual and mental labor (James, 1951). Like Marcuse subsequently, James saw children's play as the antithesis of work under capitalism. "Children express in play» he asserted, "what the worker is denied in production. Free and spontaneous play makes it possible for the child to organize himself, to associate and work with other children in his own way». Significantly, what James was referring to here was free play, which put him at the other end of the playwork spectrum to Freinet.

\section{Froebelian Revisionism}

Free versus directed play is a current binary opposition in the field of early years education in England and one that also arose during the revisionist critique of Froebelian orthodoxy. The revisionists, who included Schrader Breymann and who also drew on the work of G. Stanley Hall (1844-1924) and Dewey, criticized the use of the Gifts and Occupations in the kindergarten (Brehony, 2000). In his discussion of Froebel's educational principles, Dewey wrote, "the fact that 'play' denotes the psychological attitude of the child, not his outward performances, means complete emancipation from the necessity of following any given or prescribed system, or sequence of gifts, plays, or occupations» (Dewey, 1915: 114). Criticising Froebel's symbolism, Dewey argued that in their play, children should reproduce not symbols but realities which were of, «as familiar, direct, and real a character as possible». Like Schrader Breymann, whose reading of Froebel was praised by G. Stanley Hall (Hall, 1911: 16), held that it was, «the home life in its setting of house, furniture, utensils, etc., together with the occupations carried on in the home, offers, accordingly, material which is in a direct and real relationship to the child» (Dewey, 1915: 120) and that play should be organized around them accordingly. This led to a selective rejection of the Gifts and Occupations by the revisionists but as Prochner has shown, this was far from universal (Prochner, 2009). The Occupations with their link to manual training appear to have been rejected the most and some, like Montessori, criticized these as not being suited to children's physiological development (Montessori, 1912). Alongside the Occupations, the expressivist metaphysic was abandoned and its place filled with empirical study of a positivist flavour (Brehony, 2009). Outside Marxist circles, as has been noted, the Romantic and Idealist conception of work was in retreat. This is evident from a consideration of the articles that appeared in Child Life, the English Froebelian journal. At the turn of the nineteenth century and the early years of the 
twentieth there was much discussion of play and work in this journal as exemplified by an article entitled, "The distinction between work and play» written by H. L. Withers, Professor of Education at Owens College, Manchester in 1902 (Withers, 1902). After 1920, however, articles on play in the journal were rare and work was hardly mentioned.

\section{Conclusion}

I have tried to show in this article, how Froebel's thinking on play was indissolubly linked to his view of work and how that, in turn, had affinities with the German Romantic and Idealist tradition that Marx and subsequent Marxists drew upon. At its centre was a conception of the dual nature of work; at once both potentially liberating and oppressive and alienating. For many, the solution to work as a curse was the transformation of work into play, as play, alongside artistic work, seemed to be the antithesis of work. For Froebel this was not the case as play and work were points on a continuum; a conception repeated by Dewey. Marx rejected the notion that work could become play, and together with Hegel, the idea that play should form a part of schooling. They did not consider, as had Froebel, that play should be an integral part of the education of children in their early years but neither is there much warrant for the view that Froebel would have disagreed with Hegel and Marx on play, other than playground games, in the process of schooling.
It is tempting to speculate that the decline of the Romantic and Idealist metaphysics of work in relation to young children's education, was in part brought about by the gradually growing distance between infancy and entry into work as the length of compulsory schooling increased. Accompanying this was a growing prohibition and stimatization of child labour. This might also be related to the rise of psychology that came to dominate the field of early years' education and which in Freinet's view led to a neglect of work in favour of play Education through work : a model for cFreinet and Sivell, 1993: 207-208). Psychology, to adapt Dewey's binary, was child, not society, centered (Dewey, 1915).

Of course, the debate about play, work and education did not end with the revisionist Froebelians. In 1936, Montessori called a chapter in her book The Secret of Childhood, homo laborans, in which she raised a number of questions regarding the role of work in a child's development (Montessori and Carter, 1936). Currently, the place of play in early years education is under threat in many societies as the neo-liberal emphasis on work and pre-school, conceived solely as preparation for school, in the belief that schooling is the key to economic success in conditions of globalization, bids to become hegemonic. A moment's reflection on the nature of work, and its increasing absence, that took account of the debates and discussion charted here, might lead to a different conclusion.

\section{Referencias bibliográficas}

Adorno, T. W.; Adorno, G.; and Rolf Tiedemann, R. (1997). Aesthetic theory. London, Athlone Press.

Allen, A. T. (1982). Spiritual Motherhood: German Feminists and the Kindergarten Movement 1848-1911. History of Education Quarterly 22 (3): 319-339.

Beattie, N. (2002). The Freinet movements of France, Italy, and Germany, 1920-2000: versions of educational progressivism. Lewiston, N.Y.; Lampeter, E. Mellen Press. 
Kevin J. Brehony

BEISER, F. C. (2003). The romantic imperative: the concept of early German romanticism. Cambridge, Mass.; London, Harvard University Press.

Benedict, S. A. o. M. C. and Blair, D. O. H. S. (1886). The Rule of our Most Holy Father Saint Benedict. London, Burns \& Oates.

Blanco, C. S. and BerRIO, J. R. (2010). Historia y perspectiva actual de la educación infantil, Grao.

BREHONY, K. J. (1998). I used to get mad at my school: Representations of schooling in rock and pop music. British Journal Sociology of Education 19 (1): 113-134.

Brenony, K. J. (1998). Even far distant Japan is «showing an interest»: the English Froebel movement's turn to Sloyd. History of Education 27 (3): 279-295.

Brehony, K. J. (2000). English revisionist Froebelians and the schooling of the urban poor in. P. HirSCH and M. Hilton (eds.), Practical Visionaries: Women, Education and Social Progress 17901930. London, Longman: 183-199.

Brenony, K. J. (2009). Transforming theories of childhood and early childhood education: child study and the empirical assault on Froebelian rationalism. Paedagogica Historica 45 (4): 585604.

BREHONY, K. J. (2010). Froebel's religious beliefs: The transition from alternative to oppositional and its bearing on the diffusion of the kindergarten post 1848, in. K. Neumann, U. SAUERBREY and M. WinkLER (eds.) Frobelpadagogik im Kontext der Moderne. Bildung Erziehung und soziales Handeln Jena, IKS Garamond: 73-92.

Breymann, H. J. J., Schrader, H. J. J., et al. (1872). Die Grundzüge der Ideen Friedrich Fröbel's angewendet auf Kinderstube und Kindergarten.

Brown, M. H. and FreEmAn, N. K. (2001). We don't play that way at preschool: the moral and ethical dimensions of controlling children's play, in. S. ReIFEL and H. BROWN MAC (eds.) Early education and care, and reconceptualizing play Amsterdam; London, Jai: 259-274.

BukHarin, N. and Preobrazhensky, E. (2001). The ABC of Communism. Retrieved 29th June, 2012, from http://www.marxists.org/archive/bukharin/works/1920/abc/10.htm.

Bülow-Wendhausen, B. (1901). The life of the Baroness von Marenholtz-Bülow. New York, W.B. Harison.

Carlyle, T. (1870). Past and present. London, Chapman and Hall.

CleARY, J. J. (ed.) (1997). The perennial tradition of Neoplatonism. Ancient and medieval philosophy. 24 Series 1; Leuven, Belgium, Leuven University Press.

Derrida, J., A. BASS, et al. (1981). Positions. London, Athlone Press.

Dewey, J. (1915). The school and society. Chicago, University of Chicago Press.

Dewey, J. (1921). Democracy and Education. An Introduction to the Philosophy of Education. New York, The Macmillan Company.

Engels, F. and McLellan, D. (2009). The condition of the working class in England in 1844. Oxford, Oxford University Press.

Freinet, C. l. and Sivell, J. (1993). Education through work: a model for child-centered learning. Lewiston, N.Y.; Lampeter, Edwin Mellen.

Freud, S. and C. Hubback, J. M. (1922). Beyond the pleasure principle. London; Vienna, International Psycho-analytical Press.

Froebel, F. W. A. (2001a). Friedrich Froebel's The education of man, in K. J. Brehony (ed.), The origins of nursery education: Friedrich Froebel and the English system, vol. 1. London, Routledge.

Froebel, F. W. A. (2001b). Froebel's Letters on the kindergarten, in K. J. Brehony (ed.), The origins of nursery education: Friedrich Froebel and the English system, vol. 2. London, Routledge.

72 • Bordón 65 (I), 2013, 59-77, ISSN: 0210-5934 
Play, Work and Education: Situating a Froebelian Debate

Froebel, F. W. A. (2001c). Friedrich Froebel's education by development, in K. J. Brehony (ed.), The origins of nursery education: Friedrich Froebel and the English system, vol. 4. London, Routledge.

Froebel, F. W. A. (2001d). Mother's songs and selected writings, in K. J. Brehony (ed.), The origins of nursery education: Friedrich Froebel and the English system,, vol. 5. London, Routledge.

Froebel, F. W. A., Moore, H. K., et al. (1915). Autobiography of Friedrich Froebel. London, Allen \& Unwin.

Froebel, K. (1863). The Kindergarten, The Museum: a quarterly magazine of education, literature and science X(July): 180-188.

Froebel, K. (1875). Explanation of the kindergarten for those who are not satisfied with the present results of education, and search for principles which promise social improvement. London, G. Philip $\&$ Son.

GibBons, B. J. (2001). Spirituality and the occult: from the Renaissance to the modern age. London, Routledge.

Goetze, W. (1894). Illustrated manual of Hand and Eye Training on educational principles, etc. London, Newmann \& Co.

Great Britain. Board of Education (1912). Report of the Board of Education 1910-11. London, HMSO.

Hall, G. S. (1911). The pedagogy of the kindergarten, in. G. S. Hall (ed.), Educational Problems New York and London, D. Appleton and Company. 1: 1-41.

Hans, N. A. (2011). The Russian tradition in education London, Routledge.

HANs, N. and S. Hessen, I. (1930). Educational policy in soviet Russia. London, P. S. King \& son.

HEERWART, E. (1884). The Kindergarten in relation to the various industrial products, in INTERNAtional Health Exhibition (ed.), The Health Exhibition Literature London, William Clowes. XIII: 96-105.

HeErwart, E. (1891). What led Froebel to invent kindergarten occupations?, Child life 1 (2): 22-24.

Hegel, G. W. F. (1998). Aesthetics: Lectures on Fine Art. Oxford, Oxford University Press.

Hegel, G. W. F. and Findlay, J. N. (1979). Phenomenology of spirit. Oxford, Oxford University Press.

Hegel, G. W. F., Boumann, L. et al. (1971). Hegel's Philosophy of mind: being part three of the Encyclopaedia of the philosophical sciences (1830). Oxford, Clarendon Press.

Holman, H. (1921). Hand and Eye Training. London, Sir Isaac Pitman.

Hughes, F. P. (2009). Children, play, and development. London, Sage Publications, Inc.

Huizinga, J. (1998). Homo ludens: a study of the play-element in culture. London, Routledge.

ISAACS, S. S. F. and ISAACS, N. (1930). Intellectual growth in young children, G. Routledge \& sons ltd.

JAMES, C. L. R. (1951). On the woman question: An orientation. Retrieved 2nd July, 2012, from http://www.marxists.org/archive/james-clr/works/articles/woman51.htm.

KANT, I. and J. H. s. B. o. BERnARD, O. F. (1914). Kant's Critique of Judgement. Translated, with introduction and notes, by J. H. Bernard... Second edition, revised. London, Macmillan \& Co.

Kellner, D. (1984). Herbert Marcuse and the crisis of Marxism, Univ of California Press.

Kirschenbaum, L. A. (2001). Small comrades: revolutionizing childhood in Soviet Russia, 1917-1932. New York; London, Routledge Falmer.

KoJĖVE, A. and QueneAu, R. (1980). Introduction to the reading of Hegel: lectures on the phenomenology of spirit. Ithaca, N. Y., Cornell University Press.

Lloyd, A. C. (1998). The Anatomy of Neoplatonism Oxford, Oxford University Press.

Löwy, M. (1987). The Romantic and the Marxist critique of modern civilization. Theory and Society 16(6): 891-904.

Löwy, M. and SAYre, R. (2001). Romanticism against the tide of modernity. Durham, NC; London, Duke University Press. 
LysChinska, M. J. (1922). Henriette Schrader-Breymann. Ihr Leben aus Briefen und Tagebüchern. Berlin \& Leipzig, Vereinigung wissenschaftlicher Verleger Walter de Gruyter \& Co.

Marcuse, H. (1969). Eros and civilization: a philosophical inquiry into Freud. London, Sphere.

Marenholtz-Bülow, B. M. von (1883). Hand Work and Head Work; their relation to one another, and the reform of education according to the principles of Froebel. London, W. Swann Sonnenschein

Marenholtz-Bülow, B. M. von (2001). Woman's Educational Mission: being an explanation of Frederick Fröbel's System of Infant Gardens, in K. J. BREHONY, (ed.), The origins of nursery education: Friedrich Froebel and the English system, vol. 5. London, Routledge, pp. 275-382.

MARENHOLTZ-BüLOW, B. M. von (1854). A connected series of playthings and occupation for early childhood. Dresden, J. F. Fischer's Printing Office.

MARENHOLtZ-Bülow, B. von (1887). Reminiscences of Friedrich Froebel. London, W.S. Sonnenschein $\&$ Co.

Marenholtz-Bülow, B. von; Mann, M. T. P. et al. (1876). The new education by work, according to Froebel's method. Camden N.J., Philotechnic Institute.

Marenholtz-Bülow, B. von; Mann, M. T. P. et al. (1877). Reminiscences of Friedrich Froebel. Boston, New York, Lee \& Shepard; C. T. Dillingham.

MarX, K. (1964). Economic and Philosophic Manuscripts of 1844. New York, International Publishers.

MARX, K. (1973). Grundrisse. Harmondsworth, Penguin Books Ltd.

MARX, K. (1977). Capital. Volume I. New York, Vintage Books.

Montessori, M. (1912). The Montessori Method. New York, Frederick Stokes.

Montessori, M. and Carter, B. (1936). The secret of childhood. London; New York [etc.], Longmans Green and co.

MORRIS, W. and WilmER, C. (2004). News from nowhere and other writings. London, Penguin.

OelKeRS, J. (2006). Work and learning: A look back and an outlook on a classical theme of education. Work, Education and Employability. Centro Stefano Franscini in Ascona.

OrzaEs, C. C. (1991). Las escuelas de párvulos en España durante el siglo XIX: su desarrollo en la Ėpoca de la Restauración. Historia de la educación: Revista interuniversitaria: 89-106.

Orzaes, M. d. C. C. (2010). La introducción de los jardines de infancia en España. Aportaciones de Pedro de Alcántara García y Eugenio Bartolomé y Mingo, in M. d. C. S. BlanCo and J. R. BerRio (eds.), Historia y perspectiva actual de la educación infantil Barcelona, Graó: 133-152.

OWEN, R. (1813). A new view of society: or, Essays on the principle of the formation of the human character, and the application of the principle to practice. Retrieved 17th October, 2005, from http://www.ecn.bris.ac.uk/het/owen/newview.txt.

PAYÁ Rico, A. (2006). La actividad lúdica en la historia de la educación española contemporânea. Departamento de Educación Comparada e Historia de la Educación, Valencia. PhD.

Pearson, M. (2002). All their Play Becomes Fruitful: The Utopian Child of Charles Fourier. Radical Philosophy: 29-39.

Piaget, J. (1962). Play, dreams, and imitation in childhood. London, Routledge \& Kegan Paul.

Pinkevitch, A. P. and Counts, G. S. (1929). The new education in the Soviet Republic. New York, John Day Co.

Prochner, L. W. (2009). A history of early childhood education in Canada, Australia, and New Zealand. Vancouver, UBC Press.

RiChTER, J. P. (1891). Levana: or, The doctrine of education. London, G. Bell.

RiCKS, G. (1889). Hand-and-eye training. Being a development of the kindergarten for junior and senior scholars. Book II. - For boys.

Rodríguez Pérez, J. F. (2007). Un maestro de maestros. Pedro de Alcantara Garcia Navarro (18421906) y la Sociedad Protectora de los Niños de Madrid. Foro de Educación (9): 133-152.

$74 \cdot$ Bordón 65 (I), 2013, 59-77, ISSN: 0210-5934 
Play, Work and Education: Situating a Froebelian Debate

RÖHRS, H. (1993). Georg Kerschensteiner (1852-1932). Prospects XXIII(3/4): 807-822.

Ruskin, J. (2007). The Stones of Venice, Volume III: The Sea Storis. New York, Cosimo Classics.

SAYERS, S. (2011). Marx and Alienation; Essays on Hegelian Themes. Basingstoke, Palgrave, McMillan.

Sayre, R. and Löwy, M. (1984). Figures of Romantic Anti-Capitalism. New German Critique (32): 42-92.

SCHILLER, F. (1994). On the aesthetic education of man: in a series of letters. Bristol, Thoemmes.

SMALl, R. (2005). Marx and education, Ashgate Pub Co.

SPENCER, D. A. (2009). The political economy of work. Abingdon, Routledge.

STOW, D. (1847). National education: the duty of England in regard to the moral and intellectual elevation of the poor and working classes: teaching or training? London, J. Hatchard.

Sutton-Smith, B. (2001). The ambiguity of play. Cambridge, Mass.; London, Harvard University Press.

TAYLOR, C. (1989). Sources of the Self: The Making of Modern Identity. Cambridge, Mass, Harvard University Press.

The Holy Bible (1997). The Holy Bible: containing the Old and New Testament: translated out of the original tongues and with the former translations diligently compared and revised by His Majesty's special command.containing the Old and New Testament. Cambridge, Cambridge University Press

Valkanova, Y. (2009). The Passion for Educating the New Man: Debates about Preschooling in Soviet Russia, 1917-1925. History of Education Quarterly 49 (2): 211-221.

Vygotsky, L. (1978). Mind in Society. Cambridge, Harvard University Press.

WALLERSTEIN, I. M. (2011). Historical capitalism: with capitalist civilization. London, Verso.

WesLEY, J. (1841). The works of the Rev. John Wesley: Volume XIII: Fourth edition, with the last corrections of the author. London, John Mason.

White, J. (1905). The educational ideas of Froebel. London, W.B. Clive.

WiLDERSPIN, S. (1834). The Infant System, for developing the intellectual and moral powers of all children, from one to seven years of age.

Withers, H. L. (1902). The distinction between work and play. Child Life [online] IV, 33-40.

ZELDin, D. (1969). The educational ideas of Charles Fourier, 1772-1837. London, Frank Cass.

\section{Resumen}

\section{Juego, trabajo y educación: situando un debate froebeliano}

En la actualidad, se discute acerca del lugar del juego en la escuela y en la educación. Incluso en la enseñanza preescolar, donde es más probable encontrarlo, su situación es a menudo precaria. En este artículo se indica que en muchas tradiciones religiosas antiguas, el juego es visto a veces como algo pecaminoso, mientras que en el trabajo, su antítesis, se ve algo virtuoso. El educador alemán Friedrich Froebel se apartó radicalmente de estas valoraciones, e ideó un sistema de juego educativo basado en juguetes y juegos organizados para ser usados en su institución de educación de los niños pequeños, el kindergarten. Sin embargo, al mismo tiempo que era un destacado defensor de la idea del juego como una parte valiosa y necesaria del currículo infantil, Froebel subordinó su valor a lo que se pretendía llegar, el trabajo de carácter manual.

La lectura de Froebel y el movimiento froebeliano que se presenta aquí sitúa sus concepciones del juego y del trabajo en el contexto intelectual del romanticismo alemán y la filosofía idealista. Los contornos principales de pensamiento sobre el juego y el trabajo se trazan en los escritos de Kant, Schiller, Hegel y Marx, a través de una consideración del trabajo como algo al mismo tiempo

Bordón 65 (I), 2013, 59-77, 15SN: 0210-5934・75 
Kevin J. Brehony

emancipatorio y alienante. Este tema se desarrolla en el pensamiento de los principales románticos ingleses y diversos representantes de la tradición marxista, incluidos algunos apegados a la ideología soviética.

Se mantiene que los revisionistas de Froebel, como Schrader Breymann y muchos froebelianos inspirados por G. Stanley Hall y John Dewey, tendieron a abandonar la visión del trabajo adoptada por Froebel y a focalizarse más en el juego, ayudados por los intereses y hallazgos del campo en desarrollo de la psicología y el impulso de la escolaridad obligatoria.

Palabras clave: juego, trabajo, Froebel, jardin de la infancia, Romanticismo, Idealismo.

\section{Résumé}

\section{Le jeu, le travail et l'éducation: pour situer un débat Froebélien}

Présentement, la place du jeu dans l'école et l'éducation est controversée. Même à la maternelle, où il est plus vraisemblable de le trouver, son statut est souvent précaire. Cet article note que dans les traditions religieuses anciennes, le jeu est souvent vu comme un vice tandis que le travail, son antithèse, est vu comme une vertu. Friedrich Fröbel, le pédagogue allemand, s'est séparé radicalement de ces évaluations et a inventé un système de jeu éducatif à base de jouets et de jeux à être utilisés à la maternelle, son institution pour l'éducation des jeunes enfants, le kindergarten. Néanmoins, tout en étant avocat éminent de la notion du jeu comme partie valable et nécessaire du programme de la petite enfance, Fröbel considérait le jeu de moindre valeur que le travail manuel, auquel il était supposé conduire.

La lecture de Fröbel et le mouvement de Fröbel présentés ici situent sa conception du jeu et du travail dans le contexte intellectuel du Romantisme allemand et de la philosophie Idéaliste. Les principaux contours de la pensée sur le jeu et le travail sont tracés dans les écrits de Kant, Schiller, Hegel et Marx, à travers une considération du travail comme étant émancipant et aliénant tout à la fois. Ce thème est poursuivi dans la pensée de Romantiques anglais majeurs et de figures variées au sein de la tradition marxiste, incluant certains penseurs attachés à l'idéologie soviétique.

Nous argumentons que les révisionnistes de Fröbel, comme Schrader Breymann et beaucoup de Froebéliens inspirés par G. Stanley Hall et John Dewey, ont eu tendance à abandonner la vision du travail embrassée par Fröbel et à miser plutôt sur le jeu, appuyés par les intérêts et les conclusions du domaine de la psychologie en croissance ainsi que par la prolongation obligatoire de la scolarité.

Mots clés: le jeu, le travail, Fröbel, la maternelle, le Romantisme, l'Idéalisme. 
Play, Work and Education: Situating a Froebelian Debate

\section{Perfil profesional del autor}

\section{Kevin J. Brehony}

Desempeña la Cátedra Froebel de Early Childhood Studies y dirige el Early Childhood Research Centre en University of Roehampton, Londres. Consejero de la National Froebel Foundation, miembro del Froebel Research Committee y presidente de la International Froebel Society. Ha sido profesor en University of Reading, en Edge Hill College of Education y en Open University. Empezó su carrera en la educación como maestro en tres escuelas primarias en el área de West Midlands. Autor de numerosos trabajos, entre ellos, el libro The origins of nursery education: Friedrich Froebel and the English system (London, Routledge, 2001).

Correo electrónico de contacto: K.Brehony@roehampton.ac.uk 